\title{
PRIORITY EVENTS DETERMINATION FOR THE RISK-ORIENTED MANAGEMENT OF ELECTRIC POWER SYSTEM
}

\author{
Mykola Kosterev \\ Department of power plant \\ National technical university of Ukraine "Igor Sikorsky Kiev Polytechnic institute" \\ 37 Peremohy ave., Kyiv, Ukraine, 03056 \\ Volodymyr Litvinov \\ PJSC "Ukrhydroenergo", affiliate "Dnipro HPP" \\ Winter blvd., 1, Zaporizhia, Ukraine, 69096
}

\begin{abstract}
The task of risk-oriented management of the electric power system in conditions of multi-criteria choice is considered. To determine the most effective measures, the implementation of which will reduce the magnitude of the risk of an emergency situation, multi-criteria analysis methods are applied. A comparative analysis of the multi-criteria alternative (ELECTRE) ranking method based on utility theory and the Pareto method, which defines a subset of non-dominant alternatives, is carried out. The Pareto method uses in its algorithm only qualitative characteristics of the advantage and allows only to distinguish a group of competitive solutions with the same degrees of non-dominance. Given the large number of evaluation criteria, the Pareto method is ineffective because the resulting subset of activities is in the field of effective trade-offs, when no element of the set of measures can be improved without degrading at least one of the other elements. The ELECTRE method is a pairwise comparison of multi-criteria alternatives based on utility theory. This method allows to identify a subset of the most effective activities. The number of elements of the resultant subset is regulated by taking into account the coefficients of importance of optimization criteria and expert preferences.
\end{abstract}

Keywords: electric power system, multi-criteria choice, ELECTRE method, Pareto method, importance factor.

\section{Introduction}

In recent years, Ukraine's electric power system (EPS) has been operating in extremely tense regimes, which is a consequence of the deterioration of its equipment, low rates of its replacement and modernization, violation of a number of interconnections, etc. In such conditions, it is important to organize the EPS optimal management, which should include:

1) management of the EPS regime taking into account the actual technical condition of the equipment;

2) equipment modernization taking into account the structural, regime and technical reliability of the EPS;

3) optimal allocation of available resources and resources to ensure maximum reliability of the EPS operation;

4) planning the EPS development as a multi-criteria decision-making task.

Studies of modern world approaches to the organization of effective and reliable EPS management show significant prospects for using risk-based management, the main quantitative characteristic of which is risk [1]. The risk is a product of the probability of the occurrence of an accident and its consequences [2] and is a quantitative characteristic of the EPS reliability over a time interval. By the magnitude of the risk, the expert either makes a decision about its admissibility in the time interval under consideration, or whether it is expedient to reduce it. To reduce the magnitude of the risk of an EPS emergency, it is necessary to use the measures that are most effectively chosen as one of the main objectives of the EPS preventive management [1].

\section{Literature review}

In [3] the approach to complex application of risk management in distribution networks is presented. The results of the evaluation of the operation of the distribution network equipment and their application in the aging models of the equipment are provided to obtain a forecast of 
the reliability of the operation of the EEC, depending on the chosen risk management strategy. In $[4,5]$ approaches have been developed to predict the reliability of the EPS operation with a large number of renewable energy sources per day in terms of the absence of overloads of its elements. Risk assessment is carried out under conditions of a large number of uncertainties. In [6, 7], the fuzzy-statistical approach to determining the risk of an accident in the EPS is presented, according to which the risk is determined in conditions of incompleteness of the initial information taking into account the state of the equipment.

In [1], a method of weak optimality is used to determine the most appropriate preventive measure for reducing the risk of an accident in the electric power system under multi-criteria choice conditions. The importance of selection criteria is determined by agreeing expert judgments on the Saaty pair-wise comparison method.

The main disadvantage of the proposed approach is that the optimal solution, which is chosen on the basis of the Pareto multi-criteria method, should always be in the field of effective trade-offs, when no element of the solution set can be improved without worsening at least one of the other elements [8]. This can lead to ambiguity in determining the best measure by assigning the same degrees of non-dominance to several activities, especially when a large number of alternatives are considered.

In powerful, ramified EPS, if necessary to reduce the risk of an emergency situation, the number of possible measures is significant. The Pareto method uses in its algorithm only qualitative characteristics of the advantage and allows only to distinguish a group of competitive solutions with the same degrees of non-dominance. Thus, it is necessary to use other approaches to determine the most effective solution among the competitive ones.

\section{Materials and methods}

Let's consider the EPS in which risk assessment of an emergency situation is made with a probability-statistical approach $[1,6,9]$. The result obtained by the experts recognizes that it requires a reduction in the EPS reliable operation. There are many measures $A=\left\{A_{1}, A_{2}, \ldots, A_{n}\right\}$ to reduce the risk.

There are a number of criteria $A=\left\{A_{1}, A_{2}, \ldots, A_{n}\right\}$ that assess the effectiveness of the proposed risk reduction measures. The main quantitative characteristic of each criterion is its weighting factor of importance. The sum of the weighting coefficients of the importance of all criteria is 1 .

A significant number of possible measures and criteria for assessing their effectiveness determine the task of reducing risk in the EPS as a multi-criteria optimization problem. This task is difficult to solve using deterministic optimization methods for the following reasons:

- a large number of activities and criteria for their effectiveness;

- measures are not alternative, that is, a combination of several measures is possible to achieve the greatest effect.

In such conditions, it is advisable to apply fuzzy optimization methods that allow to identify a subset of competitive activities. According to the theory of decision making [10,11], the task is related to the group of problems in which it is required to determine the best alternative or group of competitive alternatives, provided that each of the $n$ alternatives has a quantitative estimate for each of the $\mathrm{m}$ criteria. One of the methods that best suits this type of task is the method of ranking multi-criteria alternatives $[10,12,13]$.

The method of ranking multi-criteria alternatives. The ELECTRE method (Elimination Et Choix Traduisant la Realitie) is a method of pair-wise comparison of multi-criteria alternatives based on utility theory. In this method, the quantitative value of the quality indicator of each of the alternatives is not determined, but the condition for the superiority of one alternative over another is established $[10,14]$. When evaluating the advantages of one alternative over another, the weight of the criteria is taken into account.

To use this method, it is necessary the following input data:

1) a list of criteria $\mathrm{C} 1 \ldots \mathrm{Cn}$;

2) a list of alternatives A1...Am;

3) quantitative estimates of alternatives according to the criteria $a_{11} \ldots a_{i j} \ldots a_{m n}$;

4) the weighting coefficients of the importance of the criteria $w_{1} \ldots w_{n}$. 
Based on the quantitative estimates of the two alternatives $\left(A_{i}, A_{j} ; i, j=1, \ldots, m ; i \neq j\right)$ the quantitative values of the two criteria are determined: agreement and disagreement. These indices determine agreement and disagreement with the hypothesis that the alternative $\mathrm{A}_{\mathrm{i}}$ is dominated by the alternative $A_{j}$.

Experts set the values of the criteria of agreement and disagreement with which the indexes for each pair of alternatives are calculated. If the agreement index is higher than the specified value, and the disagreement index is lower, then one of the alternatives is dominated by the other, which should be excluded from the set of alternatives. Alternatives to the remaining form the first "core".

The values of the criteria of agreement and disagreement vary (the size of the consent criterion is smaller and the value of the disagreement criterion is larger in size), for which "cores" are distinguished with fewer alternatives. The last "core" includes the best alternatives. Their sequence determines the orderliness of alternatives in quality. The algorithm of the method is as follows [11, 14]:

1) A hypothesis is advanced about the advantages of alternative $A$ and over alternative $A_{j}$. The set $\mathrm{C}$ consisting of $\mathrm{n}$ criteria is divided into three subsets:

$-\mathrm{C}^{+}-$a subset of criteria for which $\mathrm{A}$ and is better than $\mathrm{A}_{\mathrm{j}}$;

$-\mathrm{C}^{=}-$a subset of criteria for which $\mathrm{A}$ and $\mathrm{A}_{\mathrm{j}}$ are equivalent;

$-\mathrm{C}-$ a subset of criteria for which $\mathrm{A}$ and worse than $\mathrm{A}_{\mathrm{j}}$.

2) The agreement index is formed with the hypothesis of the advantages of alternative $A$ and over alternative $\mathrm{A}_{j}$ as the ratio of the sums of the weight coefficients of the criteria for subsets $\mathrm{C}^{+}$ and $\mathrm{C}^{=}$to the total sum of the weighting coefficients:

$$
\mathrm{B}_{\mathrm{ij}}=\frac{\sum_{\mathrm{i} \in \mathrm{C}^{+}, \mathrm{C}^{=}} \omega_{\mathrm{i}}}{\sum_{\mathrm{i}=1}^{\mathrm{n}} \omega_{\mathrm{i}}} .
$$

3) The disagreement index is formed with the hypothesis of the advantages of alternative $A_{i}$ over alternative $A_{j}$ on the basis of the most "contradictory" criterion - the criterion by which $A_{j}$ is dominated by $\mathrm{A}_{\mathrm{i}}$ :

$$
\mathrm{D}_{\mathrm{ij}}=\max _{\mathrm{k} \in \mathrm{C}^{-}} \frac{\left|\mathrm{l}_{\mathrm{j}}^{\mathrm{k}}-\mathrm{l}_{\mathrm{i}}^{\mathrm{k}}\right|}{\mathrm{L}^{\mathrm{k}}},
$$

where $l_{j}^{k}, l_{i}^{k}$ - the estimates of the alternatives $A_{i}$ and $A_{j}$ for the k-th criterion, is the length of the scale of the k-th criterion.

4) A matrix of agreement indices with the put forward hypothesis is formed.

5) A matrix of disagreement indices with the put forward hypothesis is formed.

6) The experts determine the limiting values of the agreement and disagreement indices between $\mathrm{B}_{\lim 1}$ and $\mathrm{D}_{\lim 1}$. For each pair of alternatives, the indexes are compared with the limit values. If the conditions are simultaneously fulfilled $\mathrm{B}_{\mathrm{ij}} \geq \mathrm{B}_{\mathrm{cr} 1} \mathrm{D}_{\mathrm{ij}} \leq \mathrm{D}_{\mathrm{cr} 1}$ : then the alternative $\mathrm{A}_{\mathrm{i}}$ dominates over the alternative $\mathrm{A}_{\mathrm{j}}$. Since the values of both indices are within $[0 ; 1]$, for their determination, it is advisable for experts to apply the standard marks of the Harrington scale [15-17].

7) The alternative $A_{j}$ is excluded from the "core".

8) The requirements for the advantages of alternatives are relaxed: the agreement consent value is reduced to the value of $\mathrm{B}_{\lim 2}$ and the limit value of the disagreement index is increased to the value of $\mathrm{D}_{\lim 2}$. The new limit values of indices are also determined by the expert.

9) By comparing the agreement and disagreement indices, a second "core" of non-dominant alternatives is formed at the second iteration. The final number of iterations and, as a consequence, the number of alternatives in the "core" of the last iteration is determined by the expert (analyst).

A simpler method of eliminating uncompetitive options, which does not require a large number of calculations, is the Pareto method of weak optimality. The optimal solution, chosen on 
the basis of a multi-criteria approach, should always be in the field of effective trade-offs, when no element of the set can be improved without deterioration of at least one of the other elements [15].

The algorithm of the Pareto method. The alternatives form the common set of admissible solutions $\{\mathrm{A}\}=\{\mathrm{A} 1, \mathrm{~A} 2, \ldots, \mathrm{An}\}$. Each activity is described by the quantitative characteristics $\mathrm{a}_{11} \ldots \mathrm{a}_{\mathrm{ij}} \ldots \mathrm{a}_{\mathrm{mn}}$ for all $\mathrm{m}$ criteria.

The definition of the set of Pareto-effective solutions is performed according to the algorithm for constructing Pareto-optimal vectors $[13,14]$.

In accordance with the general solution of multi-criteria problems, the set of admissible solutions over the general set $\mathrm{D}$ is narrowed to the set of Pareto-efficient solutions $\mathrm{D}^{\mathrm{E}}$. The algorithm is constructed in such a way that the desired set of Pareto-optimal vectors is obtained from Y by successively removing in advance non-optimal vectors:

Step 1. Let $\mathrm{P}(\mathrm{Y})=\mathrm{Y}, \mathrm{i}=1, \mathrm{j}=2$. This forms the so-called current set of Pareto-optimal vectors, which coincides with the set $\mathrm{Y}$ in the beginning of the algorithm, and in the end - the required set of Pareto-optimal vectors.

Step 2. Check the inequality $\mathrm{y}_{\mathrm{i}} \geq \mathrm{y}_{\mathrm{j}}$. If it is true, go to step 3. Otherwise, go to step 5 . optimal.

Step 3. Remove the vector $\mathrm{y}_{\mathrm{j}}$ from the current set of vectors $\mathrm{P}(\mathrm{Y})$, since it is not Pareto-

Step 4. Verify the fulfillment of the inequality $\mathrm{j}<\mathrm{N}$. If it does, then let $\mathrm{j}=\mathrm{j}+1$ and return to step 2. Otherwise, go to step 7.

Step 5. Check the validity of the inequality $\mathrm{y}_{\mathrm{j}} \geq \mathrm{y}_{\mathrm{i}}$. If it is true, go to step 6. Otherwise, go back to step 4.

Step 6. Remove the vector $\mathrm{y}_{\mathrm{i}}$ from the current set of vectors $\mathrm{P}(\mathrm{Y})$.

Step 7. Check the fulfillment of the inequality $\mathrm{j}<\mathrm{N}-1$. If this inequality is true, we must successively let $i=i+1$, and then $j=i+1$. After this, it is necessary to return to step 2 . Otherwise (when $\mathrm{j}>\mathrm{N}-1$ ) - finish the calculations.

The choice of the optimal solution or the narrowing of the set of solutions is carried out taking into account the advantages of decision-makers. In the case of a large number of optimization criteria for achieving the qualitative fulfillment of the requirements presented in steps 2 and 5 , it is unlikely, by all criteria.

The drawback of the Pareto method is that it replaces the quantitative advantages of a qualitative relationship ("better", “worse", “equal”). As a consequence, the Pareto method can’t determine the most effective solution among the competitive ones.

To assess the effectiveness of the selected methods (ELECTRE and Pareto) in the task of forming a subset of priority measures to reduce the risk of an accident in the EPS, their comparative analysis is carried put.

\section{Experiments}

In the test 14-node EPS scheme (Fig. 1), risk assessment of a violation of dynamic stability by the probability-statistical approach presented in $[1,6,9]$ is performed.

The voltage in the balancing node No. 101 changes in the range $[0.95 ; 1.05] \mathrm{U}_{\text {nom }}$. The capacities in load nodes vary in the following ranges:

- No. 4 P $\in[860 ; 1060]$ MW, Q $\in[450 ; 550]$ MVar;

- No. 6: $\mathrm{P} \in[540 ; 660] \mathrm{MW}, \mathrm{Q} \in[180 ; 220]$ MVar;

- No. 100: $\mathrm{P} \in[585 ; 715] \mathrm{MW}, \mathrm{Q} \in[380 ; 470]$ MVar;

- No. 202: $\mathrm{P} \in[900 ; 1100] \mathrm{MW}, \mathrm{Q} \in[580 ; 720]$ MVar.

The active powers in the generation nodes are assumed to be unchanged and equal:

- No. 1: $\mathrm{P}=400 \mathrm{MW}$

- No. 3: $\mathrm{P}=400 \mathrm{MW}$

- No. 7: $\mathrm{P}=0 \mathrm{MW}$ (synchronous compensator);

- No. 201: $\mathrm{P}=1200 \mathrm{MW}$;

- No. 203: $\mathrm{P}=1200 \mathrm{MW}$.

The voltage in the generation nodes is maintained unchanged by means of automatic excitation controllers of strong action at the level of $1.05 \mathrm{U}_{\text {nom }}$. 


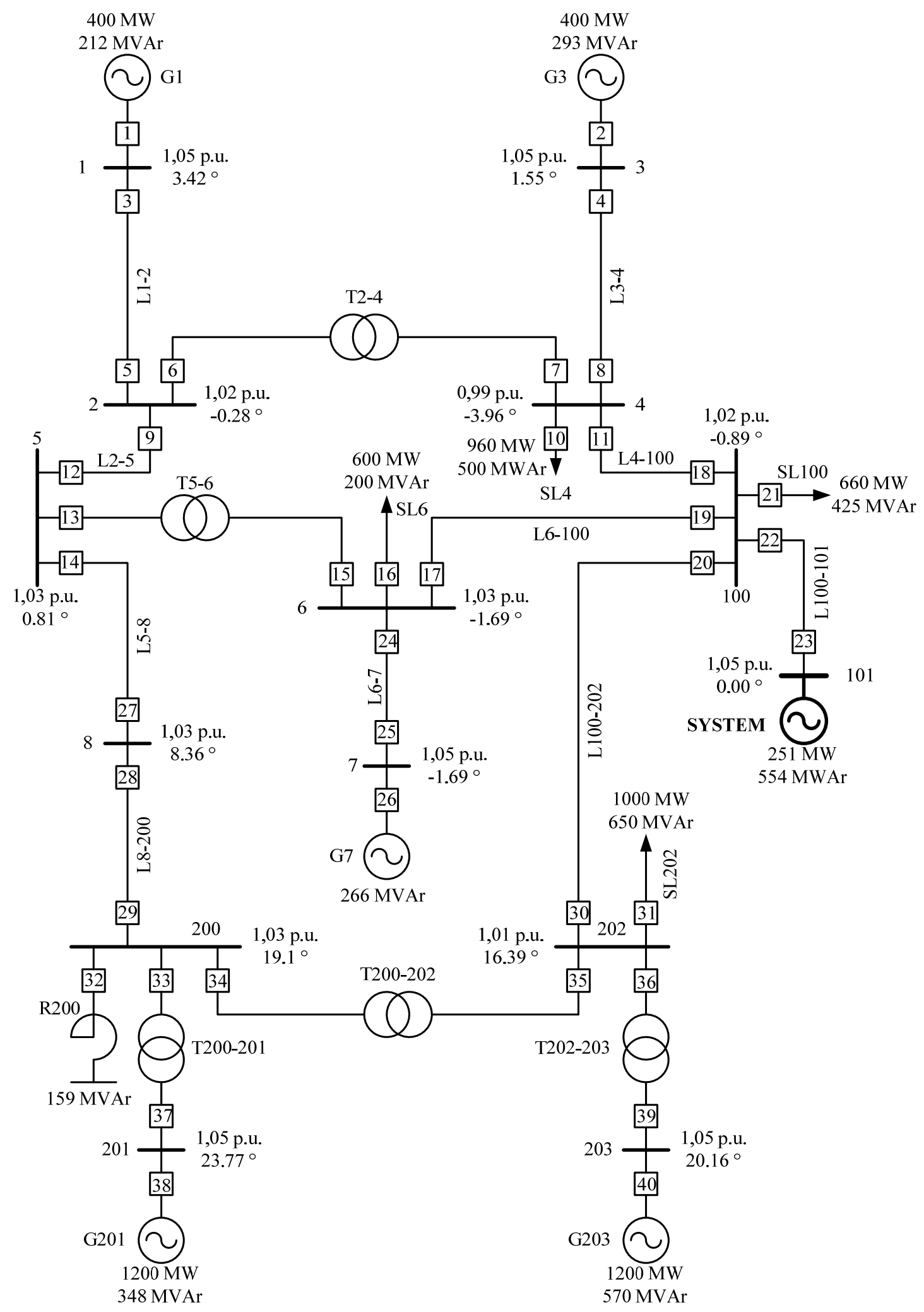

Fig. 1. 14-node EPS scheme

In this scheme, as a result of the probabilistic-statistical simulation, the risk of violation of dynamic stability $\mathrm{R}=0,29$, which is recognized by experts requiring reduction, is obtained. A lot $\mathrm{A}$ of 10 possible measures to reduce the risk of disturbance of dynamic stability are determined and their characteristics are given (Table 1). 
Table 1

A number of measures to reduce the risk of violation of dynamic stability in the EPS scheme

\begin{tabular}{|c|c|c|c|c|c|c|c|c|}
\hline \multirow[t]{2}{*}{ No. } & \multirow[t]{2}{*}{ Measure } & \multirow{2}{*}{$\begin{array}{l}\text { Risk R, } \\
\text { c.u. }\end{array}$} & \multicolumn{2}{|c|}{$\begin{array}{c}\text { Capital } \\
\text { investment } C \\
\left(C_{b}=250 \text { million }\right)\end{array}$} & \multicolumn{2}{|c|}{$\begin{array}{c}\text { Realization } \\
\text { time } \mathrm{Tr} \\
\left(\operatorname{Tr}_{\mathrm{b}}=\mathbf{2 4} \text { month) }\right.\end{array}$} & \multicolumn{2}{|c|}{$\begin{array}{l}\text { Operation time } \\
\mathrm{Te}\left(\mathrm{Te}_{\mathrm{b}}=50 \text { years }\right)\end{array}$} \\
\hline & & & $\begin{array}{l}\text { million } \\
\text { UAH }\end{array}$ & c.u. & months & c.u. & year & c.u. \\
\hline $\mathrm{A}_{1}$ & Installation of the SVS device in nodes 8 and 200 & 0.15 & 182 & 0.728 & 4 & 0.167 & 20 & 0.4 \\
\hline $\mathrm{A}_{2}$ & $\begin{array}{l}\text { Installing the the UFPC device in } \\
\text { the L100-101 branch }\end{array}$ & 0.21 & 145 & 0.58 & 3 & 0.125 & 20 & 0.4 \\
\hline $\mathrm{A}_{3}$ & Construction of a power line parallel to L5-8 & 0.2 & 100 & 0.4 & 10 & 0.417 & 40 & 0.8 \\
\hline $\mathrm{A}_{4}$ & Construction of a power line parallel to L $8-200$ & 0.16 & 140 & 0.56 & 12 & 0.5 & 40 & 0.8 \\
\hline $\mathrm{A}_{5}$ & Construction of a power line parallel to L100-202 & 0.2 & 68 & 0.272 & 8 & 0.333 & 50 & 1 \\
\hline $\mathrm{A}_{6}$ & Replacement of transformer T5-6 & 0.23 & 96 & 0.384 & 3 & 0.125 & 25 & 0.5 \\
\hline $\mathrm{A}_{7}$ & Replacement of transformer T2-4 & 0.24 & 123 & 0.492 & 3 & 0.125 & 25 & 0.5 \\
\hline $\mathrm{A}_{8}$ & $\begin{array}{l}\text { Installation of an electric braking device for a } \\
\text { turbogenerator in node } 203 \text { when a } 500 \mathrm{kV} \\
\text { transmission line is disconnected }\end{array}$ & 0.19 & 25 & 0.1 & 1 & 0.042 & 12 & 0.24 \\
\hline $\mathrm{A}_{9}$ & $\begin{array}{l}\text { Installation of a device for electric unloading of } \\
\text { the hydro-generator in node } 1 \text { when switching off } \\
\text { the } 500 \mathrm{kV} \text { transmission line }\end{array}$ & 0.15 & 32 & 0.128 & 1 & 0.042 & 12 & 0.24 \\
\hline $\mathrm{A}_{10}$ & Connecting the turbogenerator in node 3 & 0.12 & 215 & 0.86 & 24 & 1 & 30 & 0.6 \\
\hline
\end{tabular}

The effectiveness of each activity is assessed according to four criteria: of the event;

$-\mathrm{C}_{1}$ : reduction of the risk of violation of the EPS dynamic stability in the implementation

$-\mathrm{C}_{2}$ : investment in the implementation of the event;

$-\mathrm{C}_{3}$ : the period of the implementation of the event;

$-\mathrm{C}_{4}$ : the term of equipment operation, which realize the event.

The weight coefficients of the importance of the criteria are determined by the Saati method $[18,19]$. To do this, the expert determines the domination of the criteria over each other:

$-\mathrm{C}_{2}$ dominates over $\mathrm{C}_{1}$ with intensity $\mathrm{c}_{21}=2$ (very weak advantage);

$-\mathrm{C}_{1}$ dominates over $\mathrm{C}_{3}$ with intensity $\mathrm{c}_{13}=7$ (clear advantage);

$-\mathrm{C}_{3}$ dominates over $\mathrm{C}_{2}$ with intensity $\mathrm{c}_{32}=4$ (significant advantage);

$-\mathrm{C}_{1}$ dominates over $\mathrm{C}_{4}$ with intensity $\mathrm{c}_{14}=5$ (significant advantage);

$-\mathrm{C}_{4}$ dominates over $\mathrm{C}_{2}$ with intensity $\mathrm{c}_{42}=3$ (weak advantage);

$-\mathrm{C}_{4}$ dominates over $\mathrm{C}_{3}$ with intensity $\mathrm{c}_{43}=6$ (strong advantage).

By the obtained relations, a matrix of paired comparisons is computed [20]:

$$
\mathrm{A}=\left[\begin{array}{cccc}
1 & 1 / 2 & 7 & 5 \\
2 & 1 & 1 / 4 & 1 / 3 \\
1 / 7 & 4 & 1 & 1 / 6 \\
1 / 5 & 3 & 6 & 1
\end{array}\right] .
$$

The eigenvalues of the matrix are defined:

$$
\operatorname{det}|A-\lambda E|=\operatorname{det}\left[\begin{array}{cccc}
1-\lambda & 1 / 2 & 7 & 5 \\
2 & 1-\lambda & 1 / 4 & 1 / 3 \\
1 / 7 & 4 & 1-\lambda & 1 / 6 \\
1 / 5 & 3 & 6 & 1-\lambda
\end{array}\right]=0
$$


This equation has four roots:

$$
\lambda_{1}=-1,487 ; \quad \lambda_{2,3}=-0,56 \pm \mathrm{j} 3,905 ; \quad \lambda_{4}=6,607 \text {. }
$$

The eigenvalue of the matrix is the largest real positive root $\lambda_{4}=6,607$ under the substitution of which into the system of equations and the replacement of the last equation by the normalization condition

$$
\sum_{i=1}^{4} \omega_{i}=1
$$

a system of equations is formed for determining the weight coefficients of the importance of the optimization criteria:

$$
\left\{\begin{array}{l}
-5,607 \omega_{1}+0,5 \omega_{2}+7 \omega_{3}+5 \omega_{4}=0 \\
2 \omega_{1}-5,607 \omega_{2}+0,25 \omega_{3}+0,333 \omega_{4}=0 \\
0,143 \omega_{1}+4 \omega_{2}-5,607 \omega_{3}+0,167 \omega_{4}=0 \\
\omega_{1}+\omega_{2}+\omega_{3}+\omega_{4}=1
\end{array}\right.
$$

The solution of the resulting system of equations is the vector of the weight coefficients of the optimization criteria:

$$
\left[\begin{array}{l}
\omega_{1} \\
\omega_{2} \\
\omega_{3} \\
\omega_{4}
\end{array}\right]=\left[\begin{array}{c}
0,425 \\
0,173 \\
0,142 \\
0,26
\end{array}\right] .
$$

According to the algorithm of the ELECTRE method, let's define the compliance indices with the hypothesis of the advantages of alternative $A_{j}$ over the alternative $A_{j}$ for $i=1, \ldots, 10$; $\mathrm{j}=1, \ldots, 10 ; \mathrm{i} \neq \mathrm{j}$. Since the weighting coefficients $\omega$ are normalizable, the values of the indices $B$ can be obtained from the simplified expression:

$$
B_{i j}=\sum_{i \in C^{+}, C^{=}} \omega_{i} .
$$

1) $i=1, j=2$. Advantages of the criteria for alternatives:

$$
\left(\mathrm{R}_{1}<\mathrm{R}_{2}\right) \mathrm{TA}\left(\mathrm{C}_{1}>\mathrm{C}_{2}\right) \mathrm{TA}\left(\operatorname{Tr}_{1}>\operatorname{Tr}_{2}\right) \mathrm{TA}\left(\mathrm{Te}_{1}=\mathrm{Te}_{2}\right) .
$$

The subset $\mathrm{C}^{+}$is the criterion $\mathrm{C}_{1}$. The subset $\mathrm{C}^{+}$is the criterion $\mathrm{C}_{4}$.

$$
\mathrm{B}_{12}=\omega_{1}+\omega_{4}=0,425+0,26=0,685 \text {. }
$$

2) $i=1, j=3$. Advantages of the criteria for alternatives:

$$
\left(\mathrm{R}_{1}<\mathrm{R}_{3}\right) \mathrm{TA}\left(\mathrm{C}_{1}>\mathrm{C}_{3}\right) \mathrm{TA}\left(\operatorname{Tr}_{1}<\mathrm{Tr}_{3}\right) \mathrm{TA}\left(\mathrm{Te}_{1}<\mathrm{Te}_{3}\right) .
$$

The subset $\mathrm{C}^{+}$is the criteria $\mathrm{C}_{1}$ and $\mathrm{C}_{3}$. The subset $\mathrm{C}^{=}$is empty.

$$
B_{13}=\omega_{1}+\omega_{3}=0,425+0,142=0,567 \text {. }
$$


90) $\mathrm{i}=10, \mathrm{j}=9$. Advantages of the criteria for alternatives:

$$
\left(\mathrm{R}_{10}<\mathrm{R}_{9}\right) \mathrm{TA}\left(\mathrm{C}_{10}>\mathrm{C}_{9}\right) \mathrm{TA}\left(\operatorname{Tr}_{10}>\mathrm{Tr}_{9}\right) \mathrm{TA}\left(\mathrm{Te}_{10}>\mathrm{Te}_{9}\right) .
$$

The subset $\mathrm{C}^{+}$is the criteria $\mathrm{C}_{1}$ and $\mathrm{C}_{4}$. The subset $\mathrm{C}^{=}$is empty.

$$
\mathrm{B}_{109}=\omega_{1}+\omega_{4}=0,425+0,26=0,685 \text {. }
$$

Based on the obtained results, let's form the matrix of compliance indices with the hypothesis of the advantage of the $\mathrm{i}$-th element over the $\mathrm{j}$-th (Table 2).

Table 2

The matrix of agreement indices for 10 alternatives

\begin{tabular}{cccccccccccc}
\hline $\mathbf{B}$ & $\mathbf{A}_{\mathbf{1}}$ & $\mathbf{A}_{\mathbf{2}}$ & $\mathbf{A}_{\mathbf{3}}$ & $\mathbf{A}_{\mathbf{4}}$ & $\mathbf{A}_{\mathbf{5}}$ & $\mathbf{A}_{\mathbf{6}}$ & $\mathbf{A}_{\mathbf{7}}$ & $\mathbf{A}_{\mathbf{8}}$ & $\mathbf{A}_{\mathbf{9}}$ & $\mathbf{A}_{\mathbf{1 0}}$ \\
\hline $\mathbf{A}_{\mathbf{1}}$ & $*$ & 0.685 & 0.567 & 0.567 & 0.567 & 0.425 & 0.425 & 0.675 & 0.685 & 0.315 \\
$\mathbf{A}_{\mathbf{2}}$ & 0.575 & $*$ & 0.142 & 0.142 & 0.142 & 0.567 & 0.567 & 0.26 & 0.26 & 0.315 \\
$\mathbf{A}_{\mathbf{3}}$ & 0.433 & 0.858 & $*$ & 0.575 & 0.425 & 0.685 & 0.858 & 0.26 & 0.26 & 0.575 \\
$\mathbf{A}_{\mathbf{4}}$ & 0.433 & 0.858 & 0.685 & $*$ & 0.425 & 0.685 & 0.685 & 0.685 & 0.26 & 0.575 \\
$\mathbf{A}_{\mathbf{5}}$ & 0.433 & 0.858 & 1 & 0.575 & $*$ & 0.858 & 0.858 & 0.26 & 0.26 & 0.575 \\
$\mathbf{A}_{\mathbf{6}}$ & 0.575 & 0.575 & 0.315 & 0.315 & 0.142 & $*$ & 1 & 0.26 & 0.26 & 0.315 \\
$\mathbf{A}_{\mathbf{7}}$ & 0.575 & 0.575 & 0.142 & 0.315 & 0.142 & 0.402 & $*$ & 0.26 & 0.26 & 0.315 \\
$\mathbf{A}_{\mathbf{8}}$ & 0.315 & 0.74 & 0.74 & 0.315 & 0.74 & 0.74 & 0.74 & $*$ & 0.575 & 0.315 \\
$\mathbf{A}_{9}$ & 0.74 & 0.74 & 0.74 & 0.74 & 0.74 & 0.74 & 0.74 & 0.827 & $*$ & 0.315 \\
$\mathbf{A}_{\mathbf{1 0}}$ & 0.685 & 0.685 & 0.425 & 0.425 & 0.425 & 0.685 & 0.685 & 0.685 & 0.685 & $*$
\end{tabular}

Let's form the disagreement index with the hypothesis of the advantages of alternative $A_{j}$ over alternative $A_{j}$. For this, let's determine the lengths of the scales of the criteria $\mathrm{C}_{1}, \ldots, \mathrm{C}_{4}$ in conditional units according to the data in Table 1:

$$
\begin{gathered}
\mathrm{L}^{1}=\mathrm{R}_{\max }-\mathrm{R}_{\text {min }}=0,24-0,12=0,12 ; \\
\mathrm{L}^{2}=\mathrm{C}_{\text {max }}-\mathrm{C}_{\text {min }}=0,86-0,1=0,76 ; \\
\mathrm{L}^{3}=\mathrm{T}_{\mathrm{R} \max }-\mathrm{T}_{\mathrm{R} \min }=1-0,042=0,958 ; \\
\mathrm{L}^{4}=\mathrm{T}_{\mathrm{E} \max }-\mathrm{T}_{\mathrm{E} \min }=1-0,24=0,76
\end{gathered}
$$

1) $\mathrm{i}=1, \mathrm{j}=2$. The subset $\mathrm{C}^{-}$are the criteria $\mathrm{C}_{2}$ and $\mathrm{C}_{3}$.

$$
\begin{aligned}
& \mathrm{D}_{12}=\max \left\{\frac{\left|\mathrm{I}_{2}^{2}-\mathrm{l}_{1}^{2}\right|}{\mathrm{L}^{2}} ; \frac{\left|\mathrm{l}_{2}^{3}-\mathrm{l}_{1}^{3}\right|}{\mathrm{L}^{3}}\right\}= \\
& =\max \left\{\frac{|0,58-0,728|}{0,76} ; \frac{|0,125-0,167|}{0,958}\right\}=0,195 .
\end{aligned}
$$

2) $\mathrm{i}=1, \mathrm{j}=3$. The subset $\mathrm{C}^{-}$are the criteria $\mathrm{C}_{2}$ and $\mathrm{C}_{4}$. 


$$
\begin{aligned}
& \mathrm{D}_{13}=\max \left\{\frac{\left|\mathrm{l}_{3}^{2}-\mathrm{l}_{1}^{2}\right|}{\mathrm{L}^{2}} ; \frac{\left|\mathrm{I}_{3}^{4}-\mathrm{l}_{1}^{4}\right|}{\mathrm{L}^{4}}\right\}= \\
& =\max \left\{\frac{|0,4-0,728|}{0,76} ; \frac{|0,8-0,4|}{0,76}\right\}=0,526 .
\end{aligned}
$$

90) $\mathrm{i}=10, \mathrm{j}=9$. The subset $\mathrm{C}$-are the criteria $\mathrm{C}_{2}$ and $\mathrm{C}_{3}$.

$$
\begin{aligned}
& \mathrm{D}_{109}=\max \left\{\frac{\left|\mathrm{l}_{9}^{2}-\mathrm{l}_{10}^{2}\right|}{\mathrm{L}^{2}} ; \frac{\left|\mathrm{l}_{9}^{3}-\mathrm{l}_{10}^{3}\right|}{\mathrm{L}^{3}}\right\}= \\
& =\max \left\{\frac{|0,128-0,86|}{0,76} ; \frac{|0,042-1|}{0,958}\right\}=1 .
\end{aligned}
$$

Based on the obtained results, let's form the matrix of disagreement indices with the hypothesis of the advantage of the $\mathrm{i}$-th element over the $\mathrm{j}$-th (Table 3 ).

Table 3

The matrix of disagreement indices for 10 alternatives

\begin{tabular}{cccccccccccc}
\hline $\mathbf{D}$ & $\mathbf{A}_{\mathbf{1}}$ & $\mathbf{A}_{\mathbf{2}}$ & $\mathbf{A}_{\mathbf{3}}$ & $\mathbf{A}_{\mathbf{4}}$ & $\mathbf{A}_{\mathbf{5}}$ & $\mathbf{A}_{\mathbf{6}}$ & $\mathbf{A}_{\mathbf{7}}$ & $\mathbf{A}_{\mathbf{8}}$ & $\mathbf{A}_{\mathbf{9}}$ & $\mathbf{A}_{\mathbf{1 0}}$ \\
\hline $\mathbf{A}_{\mathbf{1}}$ & $*$ & 0.195 & 0.526 & 0.526 & 0.789 & 0.453 & 0.311 & 0.826 & 0.789 & 0.263 \\
$\mathbf{A}_{\mathbf{2}}$ & 0.5 & $*$ & 0.526 & 0.526 & 0.789 & 0.258 & 0.132 & 0.632 & 0.595 & 0.75 \\
$\mathbf{A}_{\mathbf{3}}$ & 0.412 & 0.305 & $*$ & 0.333 & 0.263 & 0.305 & 0.305 & 0.737 & 0.417 & 0.667 \\
$\mathbf{A}_{\mathbf{4}}$ & 0.348 & 0.391 & 0.321 & $*$ & 0.379 & 0.391 & 0.391 & 0.605 & 0.529 & 0.333 \\
$\mathbf{A}_{\mathbf{5}}$ & 0.417 & 0.217 & 0 & 0.333 & $*$ & 0.217 & 0.217 & 0.304 & 0.417 & 0.667 \\
$\mathbf{A}_{\mathbf{6}}$ & 0.667 & 0.167 & 0.395 & 0.583 & 0.658 & $*$ & 0 & 0.374 & 0.667 & 0.917 \\
$\mathbf{A}_{\mathbf{7}}$ & 0.75 & 0.25 & 0.395 & 0.667 & 0.658 & 0.142 & $*$ & 0.516 & 0.75 & 1 \\
$\mathbf{A}_{\mathbf{8}}$ & 0.333 & 0.211 & 0.737 & 0.737 & 1 & 0.342 & 0.342 & $*$ & 0.333 & 0.583 \\
$\mathbf{A}_{\mathbf{9}}$ & 0.211 & 0.211 & 0.737 & 0.737 & 1 & 0.342 & 0.342 & 0.037 & $*$ & 0.583 \\
$\mathbf{A}_{\mathbf{1 0}}$ & 0.87 & 0.913 & 0.609 & 0.522 & 0.774 & 0.913 & 0.913 & 1 & 1 & $*$
\end{tabular}

Let's determine the limiting values of the indices of agreement and disagreement between $\mathrm{B}_{\lim 1}$ and $\mathrm{D}_{\lim 1}$ using the Harrington interval scale:

1) the agreement index, according to the expert's opinion, is determined at the intervals "High" $[0.64 ; 0.8)$ and "Very high" $[0.8 ; 1]$. Thus, the limit agreement index $\mathrm{B}_{\mathrm{cr} 1}=0.64$;

2 ) the disagreement index, according to the expert's opinion, is determined at the intervals "Low" $(0.2,0.36)$ and "low" $[0 ; 0.2]$.Thus, the limiting index of disagreement $\mathrm{D}_{\text {cr1 }}=0.36$.

Let's determine the dominance of alternatives one over another on the basis of indices of agreement and disagreement:

1) $i=1, j=2 . B_{12}=0,685 \geq B_{\text {cr } 1}=0,64$ - the inequality is satisfied;

$\mathrm{D}_{12}=0,195 \leq \mathrm{D}_{\mathrm{cr} 1}=0,36-$ the inequality is satisfied.

Alternative $A_{1}$ dominates over alternative $A_{2}$. Alternative $A_{2}$. is excluded from the "core".

14) $i=3, j=7 . B_{37}=0,858 \geq B_{c r 1}=0,64-$ the inequality is satisfied;

$\mathrm{D}_{37}=0,305 \leq \mathrm{D}_{\mathrm{cr} 1}=0,36-$ the inequality is satisfied.

Alternative $\mathrm{A}_{3}$ dominates over alternative $\mathrm{A}_{7}$. Alternative $\mathrm{A}_{7}$ is excluded from the "core".

19) $\mathrm{i}=4, \mathrm{j}=3$. $\mathrm{B}_{43}=0,685 \geq \mathrm{B}_{\mathrm{cr} 1}=0,64-$ the inequality is satisfied;

$\mathrm{D}_{43}=0,321 \leq \mathrm{D}_{\mathrm{cr} 1}=0,36-$ the inequality is satisfied. 
Alternative $\mathrm{A}_{4}$ dominates over alternative $\mathrm{A}_{3}$. Alternative $\mathrm{A}_{3}$ is excluded from the "core".

34) $\mathrm{i}=9, \mathrm{j}=1 . \mathrm{B}_{91}=0,74 \geq \mathrm{B}_{\text {cr1 }}=0,64$ - the inequality is satisfied;

$\mathrm{D}_{91}=0,211 \leq \mathrm{D}_{\text {cr1 }}=0,36-$ the inequality is satisfied

Alternative $\mathrm{A}_{9}$ dominates the alternative $\mathrm{A}_{1}$. Alternative $\mathrm{A}_{1}$ is excluded from the "core".

37) $\mathrm{D}_{91}=0,211 \leq \mathrm{D}_{\text {cr1 }}=0,36$. - the inequality is satisfied;

$\mathrm{D}_{98}=0,037 \leq \mathrm{D}_{\mathrm{cr} 1}=0,36-$ the inequality is satisfied;

Alternative $\mathrm{A}_{9}$ dominates over alternative $\mathrm{A}_{8}$. Alternative $\mathrm{A}_{8}$ is excluded from the "core".

Thus, the first "core" contains four alternatives: $A_{4}, A_{5}, A_{9}, A_{10}$. To form the second "core", we form the matrices of the agreement and disagreement indices with the hypothesis of the advantage of the i-th element over the $\mathrm{j}$-th (Table 4, 5).

\section{Table 4}

Matrix of agreement indices for 4 alternatives

\begin{tabular}{ccccc}
\hline $\mathbf{B}$ & $\mathbf{A}_{\mathbf{4}}$ & $\mathbf{A}_{\mathbf{5}}$ & $\mathbf{A}_{\mathbf{9}}$ & $\mathbf{A}_{\mathbf{1 0}}$ \\
\hline $\mathbf{A}_{\mathbf{4}}$ & $*$ & 0.425 & 0.26 & 0.575 \\
$\mathbf{A}_{\mathbf{5}}$ & 0.575 & $*$ & 0.26 & 0.575 \\
$\mathbf{A}_{9}$ & 0.74 & 0.74 & $*$ & 0.315 \\
$\mathbf{A}_{\mathbf{1 0}}$ & 0.425 & 0.425 & 0.685 & $*$
\end{tabular}

\section{Table 5}

Matrix of disagreement indices for 4 alternatives

\begin{tabular}{ccccc}
\hline $\mathbf{D}$ & $\mathbf{A}_{\mathbf{4}}$ & $\mathbf{A}_{\mathbf{5}}$ & $\mathbf{A}_{\mathbf{9}}$ & $\mathbf{A}_{\mathbf{1 0}}$ \\
\hline $\mathbf{A}_{\mathbf{4}}$ & $*$ & 0.379 & 0.529 & 0.333 \\
$\mathbf{A}_{\mathbf{5}}$ & 0.333 & $*$ & 0.417 & 0.667 \\
$\mathbf{A}_{9}$ & 0.737 & 1 & $*$ & 0.583 \\
$\mathbf{A}_{\mathbf{1 0}}$ & 0.522 & 0.774 & 1 & $*$
\end{tabular}

Let's determine the weakened limiting values of the indices of agreement and disagreement of $\mathrm{B}_{\operatorname{lin} 1}$ and $\mathrm{D}_{\text {liml }}$ for the formation of the second "core" using the Harrington interval scale:

1) the agreement index, according to the expert's opinion, is determined on the intervals "Medium" [0.36; 0.64), "High" $[0.64 ; 0.8)$ and "Very high" $[0.8 ; 1]$. Thus, the limit agreement index $\mathrm{B}_{\mathrm{cr} 1}=0,36$;

2) he disagreement index, according to the expert's opinion, is determined at the intervals "Medium" $(0.36,0.64)$, "Low" $(0.2,0.36)$ and "low" $[0 ; 0.2]$. Thus, the limit disagreement index $\mathrm{D}_{\mathrm{cr} 1}=0,64$.

Let's determine the dominance of alternatives one over another on the basis of agreement and disagreement indices:

1) $i=4, j=5 . B_{45}=0,425 \geq B_{\text {cr }}=0,36$ - the inequality is satisfied;

$\mathrm{D}_{45}=0,379 \leq \mathrm{D}_{\mathrm{cr} 1}=0,64-$ the inequality is satisfied.

Alternative $A_{4}$ dominates over alternative $A_{5}$. Alternative $A_{5}$ is excluded from the "core".

3) $\mathrm{D}_{45}=0,379 \leq \mathrm{D}_{\text {cr1 }}=0,64-$ the inequality is satisfied;

$\mathrm{D}_{410}=0,333 \leq \mathrm{D}_{\mathrm{cr} 1}=0,64-$ the inequality is satisfied.

Alternative $\mathrm{A}_{4}$ dominates the alternative of $\mathrm{A}_{10}$. Alternative $\mathrm{A}_{10}$ is excluded from the "core".

The second "core" contains two alternatives: $A_{4}, A_{9}$. The expert determines the "core" of optimal solutions, obtained at the second iteration, as the final set of effective measures and stops the calculations.

Thus, a subset of the most effective measures to reduce the risk of violation of dynamic stability in the EPS test scheme contains two activities: 
$-\mathrm{A}_{4}$ - Construction of a power line parallel to L8-200;

$-\mathrm{A}_{9}$ - Installation of a device for electric unloading of the hydrogenerator in node 1 when the $500 \mathrm{kV}$ transmission line is disconnected.

From the above example, it is obvious that the disadvantage of the ELECTRE method is a large number of calculations, which grows in quadratic dependence with an increase in the number of alternatives. For comparison, let's try to determine a subset of the best solutions using the Pareto method, which takes into account only the qualitative advantages of the activities. The condition for the qualitative superiority of the $\mathrm{i}$-th sunset over the $\mathrm{j}$-th is as follows:

$$
\left\{\left(\mathrm{R}_{\mathrm{i}} \leq \mathrm{R}_{\mathrm{j}}\right) \mathrm{TA}\left(\mathrm{C}_{\mathrm{i}} \leq \mathrm{C}_{\mathrm{j}}\right) \mathrm{TA}\left(\operatorname{Tr}_{\mathrm{i}} \leq \operatorname{Tr}_{\mathrm{j}}\right) \mathrm{TA}\left(\mathrm{Te}_{\mathrm{i}} \geq \mathrm{Te}_{\mathrm{j}}\right)\right\}
$$

Let's form the set $\mathrm{A}^{\mathrm{e}}$ according to the reduced algorithm of the Pareto method:

1) $i=1, j=2$. Checking the condition (18): $\left(\mathrm{R}_{1}<\mathrm{R}_{2}\right) \mathrm{TA}\left(\mathrm{C}_{1}>\mathrm{C}_{2}\right) \mathrm{TA}\left(\operatorname{Tr}_{1}>\operatorname{Tr}_{2}\right) \mathrm{TA}\left(\mathrm{Te}_{1}=\mathrm{Te}_{2}\right)$. The condition does not hold: the considered elements are not excluded from the set $\mathrm{A}^{\mathrm{e}}$.

19) $\mathrm{i}=3, \mathrm{j}=5$. Checking the condition (18): $\left(\mathrm{R}_{3}=\mathrm{R}_{5}\right) \mathrm{TA}\left(\mathrm{C}_{3}>\mathrm{C}_{5}\right) \mathrm{TA}\left(\operatorname{Tr}_{3}>\operatorname{Tr}_{5}\right) \mathrm{TA}\left(\mathrm{Te}_{3}<\mathrm{Te}_{5}\right)$. The condition is fulfilled: the element $\mathrm{A}_{3}$ is excluded from the set $\mathrm{A}^{\mathrm{e}}$.

31) $\mathrm{i}=6, \mathrm{j}=7$. Checking the condition (18): $\left(\mathrm{R}_{6}<\mathrm{R}_{7}\right) \mathrm{TA}\left(\mathrm{C}_{6}<\mathrm{C}_{7}\right) \mathrm{TA}\left(\mathrm{Tr}_{6}=\mathrm{Tr}_{7}\right) \mathrm{TA}\left(\mathrm{Te}_{5}=\mathrm{Te}_{7}\right)$. The condition is satisfied: the element $A_{7}$ is excluded from the set $A^{e}$.

37) $\mathrm{i}=9, \mathrm{j}=10$. Checking the condition (18): $\left(\mathrm{R}_{9}>\mathrm{R}_{10}\right) \mathrm{TA}\left(\mathrm{C}_{9}<\mathrm{C}_{10}\right) \mathrm{TA}\left(\operatorname{Tr}_{9}<\mathrm{Tr}_{10}\right) \mathrm{TA}\left(\mathrm{Te}_{9}<\mathrm{Te}_{10}\right)$. The condition does not hold: no element is excluded from the set Ae.

From the initial set of activities $\mathrm{D}$, two events $\left(\mathrm{D}_{3}\right.$ and $\left.\mathrm{D}_{7}\right)$ are excluded as noncompetitive. Thus, the set of Pareto-optimal solutions $\mathrm{A}^{\mathrm{e}}$ contains 8 elements:

$$
\left\{\mathrm{A}^{\mathrm{e}}\right\}=\left\{\mathrm{A}_{1}, \mathrm{~A}_{2}, \mathrm{~A}_{4}, \mathrm{~A}_{5}, \mathrm{~A}_{6}, \mathrm{~A}_{8}, \mathrm{~A}_{9}, \mathrm{~A}_{10}\right\}
$$

The resulting set can't be further reduced by the Pareto principle. To determine the best measure, it is required to use other methods of multi-criteria optimization using the maximal operations and the weighting coefficients of the criteria.

\section{Results}

A subset of effective solutions on the set of possible solutions, defined by the ELECTRE method, consists of $n_{1}=2$ elements $\left\{A^{e}\right\}=\left\{A_{4}, A_{9}\right\}$. A subset of effective solutions on the set of possible solutions, determined by the ELECTRE method, consists of $n_{1}=8$ elements $\left\{A^{e}\right\}=\left\{A_{1}, A_{2}\right.$, $\left.\mathrm{A}_{4}, \mathrm{~A}_{5}, \mathrm{~A}_{6}, \mathrm{~A}_{8}, \mathrm{~A}_{9}, \mathrm{~A}_{10}\right\}$. The ELECTRE method allows to more effectively narrow the initial set of possible measures by taking into account the coefficients of importance of optimization criteria and expert preferences.

\section{Conclusions}

The comparative analysis of multi-criteria optimization methods in the task of forming a subset of priority measures for the organization of the most effective EPS risk management shows that the ELECTRE method allows to identify a subset of the most effective measures. The number of elements of the received subset is regulated by the expert, due to the consideration of the coefficients of importance of optimization criteria and expert preferences.

Using the Pareto method of weak optimality to discard uncompetitive options and forming an effective set of activities in the tasks of the EPS risk management does not give the desired result. This is a consequence of the fact that the resulting subset of measures is in the field of effective trade-offs, when no element of the set of measures can be improved without worsening at least one of the other elements without taking into account the weight of the optimization criteria. As a consequence, subset of Pareto-effective solutions is not much less than the output set of possible measures, and, thus, does not give an outcome to the task.

It should be noted that the ELECTRE method is more cumbersome in terms of calculations than the Pareto method. But, despite its cumbersomeness in solving problems with a large number of alternatives, which is sufficiently convenient for algorithmic programming, this disadvantage is leveled. 


\section{References}

[1] Kosteriev, M. V., Bardyk, Ye. I., Litvinov, V. V. (2014). Vyznachennia Pareto-optymalnykh rishen pry ryzyk-oriientovanomu preventyvnomu upravlinni rezhymamy elektroenerhetychnoi systemy. Hidroenerhetyka Ukrainy, 4, 51-54.

[2] Handschin, E., Jurgens, I., Neumann, C., Rehtanz, C. (2008). Long term optimization for risk-oriented asset management. $16^{\text {th }}$ Power Systems Computation Conference. Glasgow. Available at: https:// www.pscc-central.org/uploads/tx_ethpublications/pscc2008_597.pdf

[3] Zickler, U., Schnettler, A., Zhang, X., Gockenbach, E. (2007). Statistical approach for component state evaluation implemented in asset management of distribution systems. $19^{\text {th }}$ International Conference of Electricity Distribution. Vienna.

[4] Schwan, M., Schilling, C., Zickler, U., Schnettler, A. (2006). Component reliability prognosis in asset management methods. $9^{\text {th }}$ International Conference of Probabilistic Methods Applied to Power Systems. Stockholm. doi: 10.1109/pmaps.2006.360287

[5] Wang, Q. (2013). Risk-based security-constrained optimal power flow: Mathematical fundamentals computational strategies, validation, and use within electricity markets. Iowa State University, 178.

[6] Kosteriev, M. V., Bardyk, Ye. I., Litvinov, V. V. (2013). Nechitko-statystychnyi pidkhid do otsiniuvannia ekspluatatsiinoi ta rezhymnoi nadiinosti ob'iektiv pidsystem elektroenerhetychnoi systemy. Naukovi pratsi Donetskoho natsionalnoho tekhnichnoho universytetu. Seriia: «Elektrotekhnika i enerhetyka», 1 (14), 122-128.

[7] Litvinov, V. V. (2014). Nechitko-statystychnyi pidkhid do otsiniuvannia ryzyku poshkodzhennia obmotky statora hidroheneratora. Hidroenerhetyka Ukrainy, 2-3, 74-80.

[8] Orlovskiy, S. A. (1981). Problemy prinyatiya resheniy pri nechetkoy iskhodnoy informatsii. Moscow: Nauka, 208.

[9] Kosterev, M., Litvinov, V. (2016). Development of fuzzy statistical method of optimal resource allocation among technical departments of an electric utility company. Eastern-European Journal of Enterprise Technologies, 3 (4 (81)), 20-27. doi: 10.15587/1729-4061.2016.70522

[10] Larichev, O. I. (2000). Teoriya i metody prinyatiya resheniy. Moscow: Logos, 296.

[11] Larichev, O. I., Pavlova, L. I., Osipova, E. A. (1990). Mnogokriterial'nye zadachi s konstruiruemymi variantami resheniy pri ogranichennykh resursakh. Problemy i metody prinyatiya unikal'nykh i povtoryayushhikhsya resheniy, 10, 45-69.

[12] Royzenzon, G. V. (2008). Interaktivnye metody snizheniya razmernosti priznakovogo prostranstva v zadachakh mnogokriterial'nogo prinyatiya resheniy. Moscow, 25.

[13] Figueira, J. (2009). ELECTRE Methods. INESC-Coimbra, 34.

[14] Sevkli, M. (2010). An application of the fuzzy ELECTRE method for supplier selection. International Journal of Production Research, 48 (12), 3393-3405. doi: 10.1080/00207540902814355

[15] Domarev, V. V. (2002). Bezopasnost' informatsionnykh tekhnologiy. Metodologiya sozdaniya sistem zashhity. Kyiv: OOO «TID «DS», 688.

[16] Remennikov, V. B. (2005). Upravlencheskie resheniya. Minsk: Yuniti, 144.

[17] Zadeh, L. A. (1973). Outline of a New Approach to the Analysis of Complex Systems and Decision Processes. IEEE Transactions on Systems, Man, and Cybernetics, 3 (1), 28-44. doi: 10.1109/ tsmc.1973.5408575

[18] Saaty, T. L. (1990). Eigenvector and logarithmic least squares. European Journal of Operational Research, 48 (1), 156-160. doi: 10.1016/0377-2217(90)90073-k

[19] Asai, K., Vatada, D., Ivai, S. et. al.; Terano, T., Asai, K., Sugeno, M. (Eds.) (1993). Prikladnye nechetkie sistemy. Moscow: Mir, 368.

[20] Borisov, A. N., Alekseev, A. V., Merkur'ev, G. V. (1989). Obrabotka nechetkoy informatsii v sistemakh prinyatiya resheniy. Moscow: Radio i svyaz, 304.t 